through the bottom. In this way the plants were kept abundantly supplied with fresh solution. At the end of this period the differences in growth were very marked, there being a gradual increase in growth from those flooded with the weakest to those flooded with the strongest solution, the latter culture being by far the best of the series. This experiment was repeated as experiment XI., and in addition the solution of 75 parts per million was increased in concentration by the addition of 305 parts per million of sodium chloride and also of an equal amount of calcium chloride. The baskets were flooded with the solution daily for 18 days, at the end of which time they were sealed over the top with paper and paraffin to prevent evaporation from the surface of the sand, a small opening being left for the stems. The transpirations were then taken for two days and are given in Table III., together with the relative figures obtained by considering the transpiration of the first culture as 100 . The figures are relatively proportional to the size of the plants at this time.

Here the same gradation of growth is apparent in the series of different concentrations of nutrient solution as was observed in experiment XI. Furthermore, addition of either sodium chloride or calcium chloride produces a marked increase in growth. This test was repeated as experiment XII., this time taking as controls the nutrient solution in concentrations of 75 and 750 parts per million and increasing the concentration of separate portions of the weaker of these by addition of 675 parts per million of sodium chloride, of calcium sulphate and of sodium phosphate, respectively. The cultures were treated in the same manner as in experiment XI. until the twentyseventh day, after which they were sealed and weighed. The transpiration for two days is given in Table IV., together with relative figures obtained in the usual manner.

From the last three experiments it appears that in quartz sand as well as in a free solution the concentration of dissolved salts is a factor in determining plant growth, independently of any changes in the nutrient value of the medium. This may be so in ordinary soils, as well, although of course the problem here is complicated by the presence of undissolved nutrient materials in the soil. Ferric hydrate and carbon black have the same beneficial effect when mixed into many infertile soils as has been described for nutrient solutions, so that it appears that the above-mentioned hypotheses regarding toxic materials may be applied here also.

For many years experiment station workers have been studying the problem of the replacement of potassium by sodium compounds in commercial fęrtilizers. Marked increases in crop yields have been obtained by the addition of sodium chloride to soils receiving only a small amount of potassium. From the experiments here described it appears that this increase in yield may not at all be directly connected with any change in the nutritive content of the soil.

\section{BureaU of SoILs,}

J. F. Breazeale.

\section{U. S. Department of Agriculture, WASHINGTON, D. C.}

THE CLASSIFICATION OF THE ORDOVICIAN ROCKS OF OHIO AND INDIANA.

A MORE detailed study of the great mass of strata included in the Cincinnatian series of the Ordovician rocks of Ohio, Indiana and Kentucky makes necessary the classification of these strata into divisions and subdivisions of the series. This service was rendered by Mr. John M. Nickles in his papers on the Geology of Cincinnati ${ }^{1}$ and on the Richmond group in Ohio and Indiana. ${ }^{2}$

In the twenty-eighth annual report of the Indiana Geological Survey, published in 1903, the classification proposed by Nickles was adopted without change. Since the publication of this report, however, several changes in the nomenclature have seemed advisable. Some of these are due to the practise, which recently has become more general, of adopting distinct names for formations which formerly were considered approximately identical, whenever a study of their fossil faunas indicates that these formations were deposited in zoolog-

${ }^{1}$ Journal Cincinnati Soc. Nat. Hist., 1902.

${ }^{2}$ A.m. Geol., 1903. 
ical provinces essentially distinct. Now, a study of the fossil lists given by Nickles in his 'Geology of Cincinnati' indicates that the rocks at Cincinnati identified as Lorraine and Utica contain faunas so different from the typical Lorraine and Utica faunas of New York as to warrant the application of the principle above stated. For this reason the name Maysville is here suggested for the strata at Cincinnati hitherto identified as Lorraine. Along the railroad south of Maysville, Kentucky, from the first cut a little over a mile from town to the overhead bridge a mile north of Summit a magnificent series of exposures gives a complete section of all the subdivisions of the Maysville division, from the Mount Hope bed to the top of the bed formerly known as Warren. The name Eden, well defined by Orton in the first volume of the 'Geology of Ohio,' published in 1873, is revived for the strata which in the 'Geology of Cincinnati' are identified as Utica. Whether the clay bed, four or five feet thick, containing Triarthrus becki, at the base of the Eden division should be included in the Eden or not, is a question which requires further study. On the supposition that Triarthrus becki proves this clay layer to be of the same age as the Utica of New York, and that the Eden beds represent a later stage of deposition than the Utica of New York, the clay bed containing Triarthrus becki should be excluded from the Eden division. The writer, however, is not prepared to assert that the clay bed in question is the only representative at Cincinnati of the considerable thickness of black shales struck in the gas and oil wells of northern Ohio, and there identified as Utica. Nevertheless, it may be convenient to have a name for the Triarthrus horizon, and the name Fulton layer is here adopted, not because Fulton presents the best exposures, but because the names of the other localities at which this horizon occurs are already in use. Fulton was formerly a suburb of Cincinnati, and now forms part of the First Ward. ${ }^{3}$ The other localities are in Taylors Creek, east of Newport; at the quarry along the railroad, about

\footnotetext{
3 ' Geology of Cincinnati,' p. 55.
}

half a mile southeast of New Richmond, Ky.; and at Point Pleasant, $\mathrm{O}$.

Several changes in nomenclature appear advisable on account of a second practise, which has become more imperative since the publication by Weeks, in 1902, of the 'North American Geologic Formation Names.' This. practise opposes the use of the same name for different formations, even if widely separated geographically and belonging to widely different geological ages. In consequence the name Saluda was suggested in a paper on the Cincinnati geanticline in southern Kentucky ${ }^{4}$ in place of Madison, and now the name Arnheim. is proposed in place of Warren. This has the additional advantage of leading the investigator to a type locality where the characteristics of the formation can be well studied. Arnheim is a little village seven miles northeast of Georgetown in Brown County, O., and several miles east of the railroad from Georgetown to Sardinia, but is easily reached by good pikes. It makes up by the excellency of the exposures for its somewhat inconvenient location. The section begins a short distance south of town, at the Blue Banks, the first steep exposure along Straight Creek. Here the base of the Waynesville bed is twenty-five feet above the level of the creek, and the top of the Arnheim bed consists of the nodular clay layer so characteristic of the exposures of this bed in Warren County, O. The base of the Arnheim bed is a considerable distance down the stream, where it rests upon the top of the Mount Auburn bed, which contains an abundance of Platystrophia lynx at the top. The thickness of the Arnheim bed is estimated approximately at sixty-three feet.

In attempting to trace the Liberty and Whitewater beds in Indiana, the writer found great difficulty in separating these beds at any considerable distance from the type localities; for instance, at Madison, Indiana, and thence southward. For this reason it has seemed convenient to have a name for this part of the Richmond section, the Middle Richmond, when it is not found practicable readily to distinguish the smaller divisions. The name $V$ ersailles bed is here proposed. Along the

${ }^{4}$ Am. Geol., 1902. 
road at the northern edge of Versailles, Ind., both the Hebertella insculpta horizon, at the base of the Versailles bed, and the Columnaria layer, immediately below the massive Tetradium layer, at the base of the Madison bed, are well exposed.

The name Garrard, introduced by Campbell, in Folio No. 46, of the 'Geological Atlas of the United States,' 1898, may be used not only for the comparatively unfossiliferous Upper Eden beds of central Kentucky, but also for the equivalent, often richly fossiliferous, beds farther north.

Finally, the reference of the beds underlying the Eden opposite Warsaw, Ky., on the Indiana side of the Ohio River, to the Point Pleasant beds of Orton may be asserted with greater confidence, since these lower beds have been studied along the Ohio River as far east as Stony Point, a mile and a half east of Higginsport. At Point Pleasant, O., a short distance west of the town, the base of the clay layer with Triarthrus becki occurs 113 feet above the level of the river. From this level downward almost 50 feet of rock are quarried. Between the level of the river road and the river, a vertical distance of fifty-five feet, the exposures are very poor, and no quarrying operations are carried on here. It is very evident that Professor Orton referred to the quarried rocks, when proposing the name Point Pleasant beds. As late as 1893, in volume VII. of the 'Geological Survey of Ohio,' p. 4, he states distinctly that the Trenton limestone is seen only in the Point Pleasant quarries, if at all in the state. Professor Orton did not regard the quarried rocks at Point Pleasant as equivalent to the Lower or River quarry beds opposite Cincinnati, although both lie directly below the Triarthrus becki layer, and in this he has been followed by other investigators. The present writer, on the contrary, after an examination of all the exposures along the Ohio River, has come to the opposite conclusion. The observations which lead to this result are chiefly the follow ing: The most characteristic and unbiquitous fossil in these beds all along the Ohio River

${ }^{5}$ Am. Journ. of Sci., 1904, p. 329. is Eridotrypa briareus. - Even if this fossil eventually should be found in the Lexington limestone, it can not be common there, since so far it has not been detected at all. In the next place, Trinucleus concentricus is found in the upper part of these beds at many localities. It is present opposite Warsaw; opposite Cincinnati it was detected as low as eighteen feet below the top of the heavy limestone beneath the Eden section. At Point Pleasant it occurs in the upper part of the section. Whatever its range may be elsewhere, along the Ohio River it does not extend below the upper part of the rocks here identified as Point Pleasant beds. It certainly never has been found in rocks known to be of Lexington age. Again, the rocks are very much alike lithologically. This usually does not appear where the rocks have been quarried, but where much weathered along the hillsides, the similarity of the rocks at Point Pleasant and at Cincinnati often is very striking. For instance, on the hillside southwest of the railroad trestle at Foster, Ky., near railroad level, the dense, fine-grained limestones with numerous cross-sections of gastropods, and the coarse-grained, more crinoidal limestones, often wave-marked along the top, have an appearance very much like the long-exposed rocks in the Mohawkian section opposite Cincinnati. These features are not presented by the Lexington rocks in central Kentucky.

The total thickness of rocks to be included in the Point Pleasant beds, if this name is to

\begin{tabular}{|c|c|c|}
\hline Series. & Divisions. & Beds. \\
\hline \multirow{3}{*}{ Cincinnatian. } & Richmond. & $\left\{\begin{array}{l}\text { Saluda. } \\
\text { Versailles. } \\
\text { Waynesville. }\end{array}\right.$ \\
\hline & Maysville. & $\left\{\begin{array}{l}\text { Arnheim. } \\
\text { Mount Auburn. } \\
\text { Corryville. } \\
\text { Bellevue. } \\
\text { Fairmount. } \\
\text { Mount Hope. }\end{array}\right.$ \\
\hline & Eden. & $\left\{\begin{array}{l}\text { Garrard. } \\
\text { Middle Eden. } \\
\text { Lower Eden } \\
\quad(\text { Fulton layer })\end{array}\right.$ \\
\hline Mohawkian. & (Upper Beds.) & $\left\{\begin{array}{l}\text { Point Pleasant. } \\
\text { Lexington } \\
\quad(\text { top only })\end{array}\right.$ \\
\hline
\end{tabular}


be retained, probably should be approximately one hundred feet. Below this level at Moscow, Carnestown, Foster and elsewhere, rocks appear which contain Callopora multitabulata, a characteristic Lexington fossil, identified by Bassler.

With the modifications suggested in the preceding lines, the Ordovician sections in Ohio and Indiana, and in the adjacent parts of Kentucky, may be classified as on p. 151 .

Aug. F. Foerste.

DAYTon, OHIO.

\section{RECENT WORK OF THE WISCONSIN ARCHEOLOGICAL SOCIETY.}

THE recent work of the Wisconsin Archeological Society shows that it is steadily increasing in strength. It has succeeded in having passed by the state legislature bill No. $195 \mathrm{~A}$, which was introduced early in February of this year and approved June 10.

The passage of this bill is notable, since it is the first archeological measure of the state government, being the only one to receive the unanimous support of the legislature. Many such bills have been introduced during the past twenty-five years, but most of them never left the committee in which they were introduced. Every member of the society has given this legislation his hearty support. The officers profited by the fate of the several archeological bills introduced in the legislature of their sister state, Michigan, and sought advice from those interested in archeological work in that state. Profiting from the plans for work in Michigan, they have not only developed the plans, but have actually put many of them in force. They have also adopted some entirely new methods of securing information and of popularizing and disseminating it.

The officers of the society are confident that the bill is only a beginning with the popular government. By this state aid their work will be facilitated, for under the provisions of the bill all the bulletins of the society will be printed by the state. Its results, being thus brought before the citizens, will no doubt prove the right of the society to further aid from the state in the near future.
The bill, which is an amendment to section 341 , of the statutes of 1898 , provides that "There shall be printed by the state printer bimonthly, in pamphlet form, 1,500 copies of the transactions of the Wisconsin Archeological Society, on good quality book paper, uniform in style with the volumes heretofore published by said society, including necessary illustrations, not to exceed 25 pages for each copy. . . . This act shall take effect and be in force from and after its passage and publication." One hundred and thirty-three free copies of each issue are to be presented to the Wisconsin Free Library Commission for distribution among its traveling libraries.

One of the first publications to be printed under the provisions of the state printing grant will be a monograph on 'The Aboriginal Pipes of Wisconsin,' by the president of the society, Mr. George A. West. Mr. West has devoted time and money for years in securing the material upon which this monograph is based.

The society also contemplates the publication of catalogues of all the archeological specimens found in Wisconsin, including especially those now kept in institutions outside the state, in order that students of the archeology of Wisconsin may know what material is available and where it is.

The standing committee on landmarks of the Wisconsin Federation of Women's Clubs is cooperating with the Wisconsin Archeological Society. Miss Julia A. Lapham, daughter of the late Dr. Lapham, one of the greatest authorities on the archeology of Wisconsin, is chairman of this committee, which has sent circulars to the Women's Clubs of the state. These circulars ask for a report on the work done by each club in response to a general order urging the study of local history and archeology and that local action be taken to preserve ancient landmarks, including Indian mounds, and also that a Landmarks Day be arranged.in. each year's program. Records are sought of Indian trails, old military and territorial roads, trading posts, first buildings and their purposes, portages, ferries, ancient village sites, mounds; ancient 'garden-beds' 